\title{
Analysis of Bunkruptcy Prediction With Altman Z-Score, Springate and Zmijewski Models Based Engineering Science (Case study at Garuda Indonesia Airline, Period Years of 2014-2017)
}

\author{
Dailibas $^{1}$, Danny Ramdani \\ ${ }^{1}$ Economic and Business Faculty of Singaperbangsa Karawang University-Indonesia \\ dailibas@fe.unsika.ac.id \\ ${ }^{2}$ Economic and Business Faculty of Singaperbangsa Karawang University-Indonesia \\ danny.ramdani@feb.unsika. ac.id
}

Article History: Received: 11 January 2021; Accepted: 27 February 2021; Published online: 5 April 2021

\begin{abstract}
The purpose of this reseach is to analysis and to make a bunkruptcy prediction of the Garuda Indonesia listed on Indonesian Stock Exchange, and to find out what the best model used in a bunkruptcy prediction of company. Reseach method based on purposive sampling. The population of this reseach is a numbers of company financial reporting listed on Indonesian Stock Exchange, and the sample obtained from period years of 2014 to 2017. The analysis of technical data used is descriptive analysis with a helping microsoft excel software. The reseach finding, that based on Altman Z-Score, and Springate prediction model based engineering science, Company have experienced a potency of bunkruptcy since 2014 till 2017. Meanwhile Zmijewski prediction model based engineering science company has experienced a potency of bunkruptcy in 2014 and 2017. whrereas in 2015 and 2016, company is classificated as a healthy company. Based on result of the third models analysis mentioned, Zmijewski model is a better in bunkruptcy prediction of company.
\end{abstract}

Key Words : Bunkruptcy Prediction, Z-Score Altman, Springate, Zmijewski Models, Engineering Science.

\section{Introduction}

The Dynamics of a company finance performance which is influenced by a growing of business environment turbulance and stricting of an increasing competation. The alteration in an environment of business airline is extremely effected by politics,economics,social and information technology dynamic. The company that has no capabilities to adapt on environment change will have a business problem and investment risk. The company will always face some risk, especially business risk, and the risk country will creat a finance distress and bankruptcy. According to Ahmad Rodoni (2014: 189), From the financial aspect, three circumstances can cause financial distress, namely the factor of capital insufficiency or lack of capital, the amount of debt and interest burden, and suffering losses. While the causes of financial pain from macroeconomic factors are uncertainty of a country's economic conditions such as inflation and foreign exchange rates. Fifrianti and Santosa (2018), stated that condition of finance distress could be identificated earlier, before problem appears by using an early warning system model.

Many reseachers conducted a bankruptcy research, some of them have developed prediction model based engineering sciences by purpose to assist some potential investors and creditors in making choice of company where they should invest their capital, in order to protect from risk or finance distress. Some of prediction model based engineering sciences issued by Altman (1968), Springate (1978), Ohlson (1980), and Zmijewski (1983).

Development of aviation services industries in Indonesian, notably for commercial aviation schedule since the deregulation of aviation transportation was issued on 1999 by government. The aviation industries business, in puting into operation must have a big capital, and have a capabilities to adapt on changing of business environment,and it also has to follow a changing of high technology in running business as one of its competitive advantage and customers satisfactation.

Garuda Indonesian as a national and international commercial aviation and also constitutes one of Indonesian state owned enterprises, in periode years of $2014-2017$, in operating its business has a fluctuation income where company has imbalance in faring its operating. It has a total loss as US\$ 371,97 million, in year 2014 ,and got a profit as US\$77,97 million in year 2015, and the company have experienced a profit declining up to become as US\$ 9,36 million in year 2016 and in the year 2017, the company experinced a net loss as US\$ 213,38 million. All information based on financial report of company which is listed on Indonesian Stock Exchange (www.idx.com)

Based on information mentioned above, how important it is for researcher to know a potency of company bankruptcy, so the researcher conducts a reseach at Garuda Indonesia as one of Indonesian state owned enterprises, for periode years of 2014 to 2017, by using Altman Z-Score, Springate, dan Zmijewski models. 


\section{Literature Review \\ Bankruptcy}

The bankruptcy is a condition when the company has insufficient funds to run its business or failure of the company in running its operations to generate profit. Venkataramana et al. (2012) states that Bankruptcy is a situation where liabilities exceeds assets in a company, it generally occurs due to lack of capital, has no sufficient cash, the sources have properly not utilized, The management activities are inefficient, sales growth is declining, and the market situation deteriorates. Furthermore, Onakoya \& Olotu (2017) stated that bankruptcy is, when a company has no capablities to earn sufficient revenue to cover its costs, in this case, such a company has a negative economic value. Drescher (2014: 25), said that financial distress is the final stage of a liquidity crisis and potentially included in the bankruptcy stage. According to Musthafa (2017: 202), financial difficulty is a condition in which a company is unable to meet its financial obligations, both short and long term

Setiadi (2011) identified factors that make a bankruptcy of company can be classificated into two factors, namely: Internal factors, where management has no capabilities to run its business efficiently and can not fulfil their obligations, there is an inefficiency and imbalance amount of capital owned to cover total debts recently, and with the amount of debt will reduce a company profits. Fraud of management will also create a bankruptcy of company. External factors, alteration in customer demand that should be fulfilled by company, the suppliers who cannot meet raw material standard, excessive of receivables inventory, have a poor relationships with debtors, strict of business competition and global economic conditions that must be a consideration.

There are several tools used to predict the bankruptcy of a company. The bankruptcy predictors resulting from various studies conducted by experts who focus on bankruptcy at various companies in the world, there are at least three (3) models that can be used to predict bankruptcy and consist of Alman Z-Score, Springate, Zmijewski Model, Subrahmanyan, et.al (2010).

\section{The Altman Model ( Z-Score)}

The first bankruptcy prediction model based engineering science was introduced by Altman (1968), known as Almant Z-Score. This model has been widely used and still being relevant to predict a company whether it is bankrupt, in grey area or healthy, Altman, et al,(2017). In 1995, Edward Almant later modified the model, so that it can be used for predicting bankruptcy of manufacturing and non-manufacturing companies.

The modification of Altman Z-Score completely removes X5 variablel (Sales to Total Assets), because this ratio has many variation and asset size among industries. The following Z-Score equation showed after modification.

\section{$Z=6,56 X_{1}+3,26 X_{2}+6,72 X_{3}+1,05 X_{4}$}

Where

$\mathbf{Z}$ : Bankruptcy index

X1 : Working capital / total assets

X2 : Retained earnings / total assets

X3 : Earnings before interest and taxes / total assets

X4 : Market value of equity / total liabilities

The clasification of company based on Altman Z-score model, namely:

- If value of $\mathrm{Z}<1.1$, is classificated as a bankruptcy company.

- If value of $1.1<\mathrm{Z}<2.6$, is classificated as a grey area company

- If value of $\mathrm{Z}>2.6$, is classificated as a healthy company..

\section{The Springate Model (S-Score)}

This model was developed in 1978 by the Gorgon L.V. Springate. By following the procedures developed Altman, Springate using step - wise Multiple Discriminate Analysis (MDA) to make a choice of four rasio from 19 popular financial ratios that can distinguish companies are in poor zone or safe zone. The following Springate equation showed, as follow.

\section{$\mathrm{S}=1.03 \mathrm{~A}+3.07 \mathrm{~B}+0.66 \mathrm{C}+0.4 \mathrm{D}$}

Where

A : Working Capital to Total Assets

B : Net Profit Before Interest and Taxes to Total Assets

C : Net Profit Before Taxes to Current Liabilities

D : Sales to Total Asset

The limitation values used to know what the company is in a bankruptcy or a healthy zone, are: 
- If value of Springate $>0,862$, is classificated as a healthy company.

- If value of Springate $<0,862$, is classificated as a bankruptcy company.

\section{The Zmijewski Model (X-Score)}

In 1983 Zmijewski used an analysis rasio of liquidity, leverage and measure a company performance. Zmijewski made prediction with a sample of 75 companies bankruptcy, and 73 companies were healthy as long as years of 1972 - 1978,by using Indickators F-Test rasio group of rate of return, liquidity, return on return, fixed payment coverage, trends, firm size, and stock return volatility, show some significant distinction between a healthy and poor company. The model which is developed, as follow:

$\mathrm{X}=-4,3-4,5 \mathrm{X} 1+5,7 \mathrm{X} 2+0,004 \times 3$

Where:

X1 : Earning After Tax to Total Assets

$\mathrm{X} 2$ : Total Debt to Total Assets

X3 : Current Assets to Current Liabilities

Cut-off which is used in this model, namely 0 (zero), where

- $\quad$ if $\mathrm{X}$ has a positive value, it means that the company has a bankruptcy potential, whereas

- $\quad$ if $\mathrm{X}$ has more negative value, it means that the company is away from bankruptcy.

\section{Framework}

Based on description above, The framework could be described as showed on picture. 1 below

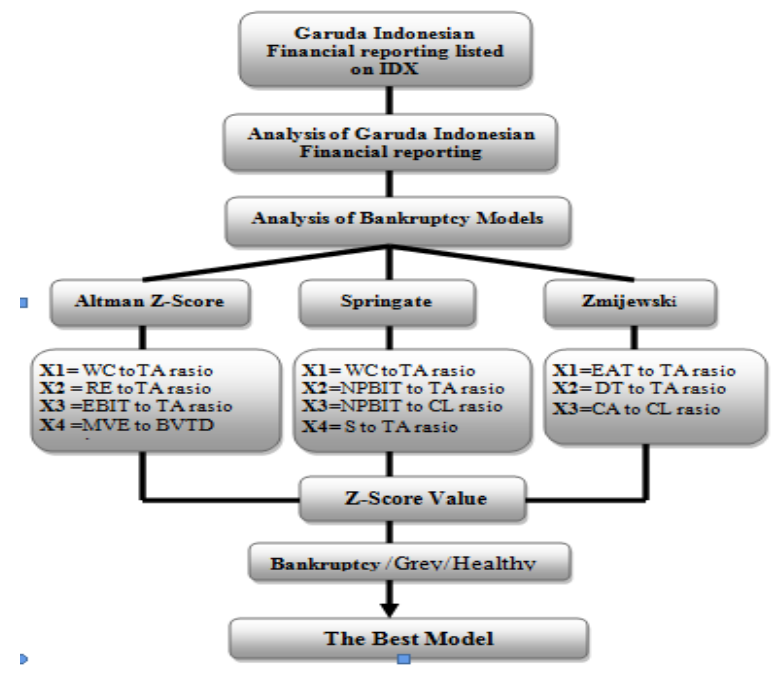

Reseach Methodology

Sample and Data.

Picture.1 Conceptual Framework

The population in this reseach are all financial report of Garuda Indonesia listed on Indonesian Stock Exchanged. The sample method used is a purposive sampling, so, the numbers of sample was taken in this research was a financial reporting of Garuda Indonesia Airline for period years of 2014 to 2017.

Method of Analysis

The Method of analysis used in this research is a descriptive analysis with a helping of software microssoft exel. The Technic of data analysis used are three models of bankruptcy prediction, namely Altman Z-Score, Springate, dan Zmijewski models

Results and Discussion

The result of all financial aspect assessment of Garuda Indonesia Airline for period years of 2014-2017, showed on tabel 1.

Tabel.1

Result of Performance Processing on Garuda Indonesia Airline

Period Years of $2014-2017$

\begin{tabular}{|l|l|c|c|c|c|c|c|c|c|}
\hline \multirow{2}{*}{ No } & \multirow{2}{*}{ DESCRIPTION } & \multicolumn{2}{|c|}{$\mathbf{2 0 1 4}$} & \multicolumn{2}{c|}{$\mathbf{2 0 1 5}$} & \multicolumn{2}{c|}{$\mathbf{2 0 1 6}$} & \multicolumn{2}{c|}{$\mathbf{2 0 1 7}$} \\
\cline { 3 - 10 } & & $\begin{array}{c}\text { VALU } \\
\text { E }\end{array}$ & SCORE & $\begin{array}{c}\text { VALU } \\
\text { E }\end{array}$ & $\begin{array}{c}\text { SCOR } \\
\text { E }\end{array}$ & $\begin{array}{c}\text { VALU } \\
\text { E }\end{array}$ & $\begin{array}{c}\text { SCOR } \\
\text { E }\end{array}$ & $\begin{array}{c}\text { VALU } \\
\text { E }\end{array}$ & $\begin{array}{c}\text { SCOR } \\
\text { E }\end{array}$ \\
\hline $\mathbf{1}$ & ROE & $-41,15$ & 0 & 8,35 & 12 & 0,94 & 2 & $-23,85$ & 0 \\
\hline $\mathbf{2}$ & ROI & 21,51 & 15 & 40,05 & 15 & $-1,53$ & 1 & $-6,15$ & 1 \\
\hline $\mathbf{3}$ & Cash Rasio & 35,62 & 5 & 43,48 & 5 & 37,01 & 5 & 15,97 & 3 \\
\hline
\end{tabular}




\begin{tabular}{|c|l|c|c|c|c|c|c|c|c|}
\hline $\mathbf{4}$ & Current Ratio & 66,47 & 0 & 84,28 & 0 & 74,52 & 0 & 51,34 & 0 \\
\hline $\mathbf{5}$ & $\begin{array}{l}\text { Collection } \\
\text { Periods }\end{array}$ & 11,19 & 5 & 11,63 & 5 & 18,07 & 5 & 20,03 & 5 \\
\hline $\mathbf{6}$ & $\begin{array}{l}\text { Return on } \\
\text { Inventory }\end{array}$ & 7,91 & 5 & 8,77 & 5 & 10,29 & 5 & 11,45 & 5 \\
\hline $\mathbf{7}$ & TATO & 129 & 5 & 115 & 4,5 & 103 & 4 & 111 & 4,5 \\
\hline $\mathbf{8}$ & TMS to TA & $-10,77$ & 0 & 2,15 & 4 & 1,58 & 4 & $-4,13$ & 0 \\
\hline & Total Score & $\mathbf{3 5}$ & & $\mathbf{5 0 , 5}$ & & $\mathbf{2 6}$ & & $\mathbf{1 8 , 5}$ \\
\hline & $\begin{array}{l}\text { Value of Health Level } \\
\text { Total Score of Equivalent } \\
\text { value is 70\%) }\end{array}$ & $\mathbf{5 0}$ & & $\mathbf{7 2 , 1 4}$ & & $\mathbf{3 7 , 1 4}$ & & $\mathbf{2 6 , 4 3}$ \\
\hline & \multicolumn{2}{|c|}{$\begin{array}{c}\text { Catagory of Health } \\
\text { In poor } \\
\text { health }\end{array}$} & & Healthy & & $\begin{array}{c}\text { In poor } \\
\text { health }\end{array}$ & & $\begin{array}{c}\text { Morbi } \\
\text { dity }\end{array}$ \\
\hline
\end{tabular}

Resources : Result of Data Processing Year 2019

Discussion of Financial Performance of Garuda Indonesia Airline, Period Years of 2014 to 2017.

\section{Return On Equity (ROE)}

As showed on table 1 above, ROE of Garuda Indonesia had a - 41,15\% value in 2014 and a - 23,85\% value in 2017 with score value was zero (0) respectively, it proved that company performance was at the worst condition. Moreover company had a 8,35\% value in 2015 with score value was 12 , and had a $0,94 \%$ value in 2016, with score value was 2 , it showed that tne company performance was fairly well in acquiring profit but the company experienced a profit declining as many $7,41 \%$.

\section{Return On Investment (ROI).}

As showed on table 1 above, ROI of Garuda Indonesia had a 21,51\% value in 2014 and a 40,05\% value in 2015 with score value was 15 respectively, it proved that company performance was a very healthy condition. But in 2016 and 2017, Company conversely experienced a declining of ROI drastically with value was $-1,53 \%$ and $-6,15 \%$ and have a 1 score respectively.It showed that the ROI of company was in the worst condition.

\section{Cash Ratio}

As showed on table 1 above, cash rasio of Garuda Indonesia, had an average of $38.70 \%$ value since 2014 till 2016 with score 5 respectively, it means that Company had a capability to run its business operation including pay for short - term debt.Meanwhile in 2017, Company conversely experienced a declining of cash rasio up to reach $15,97 \%$ with score value 3 . It proved that company was initiating to have a financial distress to run its business and pay for short - term debt.

\section{Current Ratio}

As showed on table 1 above, Garuda Indonesia experienced a fluctuation value of current ratio where company acquired $66,47 \%$ in $2014,84,28 \%$, in $2015,74,52 \%$ in 2016 , and $51,34 \%$ in tahun 2017 , cause of current ratio results were smaller than $90 \%$, so the score value were 0 (zero) respectively. It means that the last position of company current asset was smaller than the last of its current liabilities.

\section{Collection Periods (CP)}

As showed on table 1 above, the collection periods of Garuda Indonesia was tend to decline every years, where CP received for 11,19 days during 2014, 11,63 days during 2015, 18,07 days during 2016 and CP received for 20,03 during 2017, with all score value were 5 respectively. Eventhough, Company had a succesfully to discharge some claims on time, so that the company was still able to run its business.

\section{Inventory Turnover.}

As showed on table 1 above, the average of inventory turnover of Garuda Indonesia was 9.61days per year during years of 2014 - 2017, with score value was 5 resectively. Despite of company inventory turnover seems to be late, but the score value was high, it shows that the company operation activities was good to delivery revenue. Total Asset Turn Over (TATO)

As showed on table 1 above, the TATO of Garuda Indonesia had a significat value with the avarage of tato was 114,5\% per year during years of $2014-2017$, and with average of score value was 4,5. It means that the company had still capabilities to run its business optimally

\section{Capital Total to Asset Total (CT to AT)}

As showed on table 1 above, the rasio of capital total to asset total of Garuda Indonesia experienced a fluctuation value, where result of CT to AT rasio was -10,77\%, and the score was 0 (zero) in 2014, and 2,15\% wih score was 4 in 2015, and 1,58\%,with score value was 4,in 2016, and - 4,13\% with score was 0 (zero) in 
2017. All these mean that the company had no capabilities to reached maximum score (100\%) as prescripted by goverment (ministry of Indonesian state owned enterprises). And Company was in capital distress or used a bigger asset in operational. The smaller of rasio results proved that company used some debts money to fare its assets.

Finding of Bankruptcy Prediction with Altman Z-Score, Springate and Zmijewski Model on Garuda Indonesia, Periode Years of 2014 to 2017.

The Altman Z-Score Model

- Calculation $\mathrm{X}_{1}$ (Working Capital to Total Assets ratio)

- Calculation $\mathrm{X}_{2}$ (Retained Earnings to Total Assets ratio )

- Calculation $\mathrm{X}_{3}$ (Earning before interest and taxes to total assets ratio )

- Calculation $\mathrm{X}_{4}$ ( Market Value of Equity to Book Value Of Total Debt ratio )

Tabel. 2

Result of Rasio Calculation $X_{1}, X_{2}, X_{3}, X_{4}$

\begin{tabular}{|l|c|c|c|c|}
\hline Years & Score $\left(\mathbf{X}_{\mathbf{1}}\right)$ & Score $\left(\mathbf{X}_{\mathbf{2}}\right)$ & Score $\left(\mathbf{X}_{\mathbf{3}}\right)$ & Score $\left(\mathbf{X}_{\mathbf{4}}\right)$ \\
\hline $\mathbf{2 0 1 4}$ & $-0,13$ & $-0,08$ & $-0,15$ & 0,53 \\
\hline $\mathbf{2 0 1 5}$ & $-0,06$ & $-0,06$ & $-0,03$ & 0,25 \\
\hline $\mathbf{2 0 1 6}$ & $-0,11$ & $-0,06$ & -0 & 0,24 \\
\hline $\mathbf{2 0 1 7}$ & $-0,25$ & $-0,12$ & $-0,04$ & 0,20 \\
\hline
\end{tabular}

Resources : Result of Data Processing Year 2019

Calculation of Z-Score Value

\begin{tabular}{|c|c|c|c|c|}
\hline \multirow{5}{*}{$\begin{array}{c}\text { Z- Score } \\
\text { Value }\end{array}$} & \multicolumn{4}{|c|}{ YEARS } \\
\hline & 2014 & 2015 & 2016 & 2017 \\
\hline & $\begin{array}{c}=6,56 X_{1}+3,26 X_{2}+ \\
6,72 X_{3}+1,05 X_{4}\end{array}$ & $\begin{array}{l}=6,56 X_{1}+3,26 X_{2} \\
+6,72 X_{3}+1,05 X_{4}\end{array}$ & $\begin{array}{l}=6,56 X_{1}+3,26 X_{2}+ \\
6,72 X_{3}+1,05 X_{4}\end{array}$ & $\begin{array}{l}=6,56 X_{1}+3,26 X_{2} \\
+6,72 X_{3}+1,05 X_{4}\end{array}$ \\
\hline & $\begin{array}{l}=6,56(-0,13)+3,26(- \\
0,08)+6,72(-0,15)+ \\
1,05(0,53)\end{array}$ & $\begin{array}{l}=6,56(-0,06)+3,26 \\
(-0,06)+6,72 \quad(- \\
0,03)+1,05(0,25)\end{array}$ & $\begin{array}{l}=6,56(-0,11)+3,26 \\
(-0,06)+6,72(0)+ \\
1,05(0,24)\end{array}$ & $\begin{array}{l}=6,56(-0,25)+3,26 \\
(-0,12)+6,72(-0,04) \\
+1,05(0,20)\end{array}$ \\
\hline & $=-1,5651$ & $=-0,1251$ & $=-0,6652$ & $=-2,09$ \\
\hline
\end{tabular}

The Springate Model

- Calculation $\mathrm{X}_{1}$ (Working Capital to Total Assets ratio )

- Calculation $\mathrm{X}_{2}$ (Net Profit Before Iinterest \& Taxes to Total Assets ratio)

- Calculation X3 (Net Profit Before Taxes to Current Liabilities ratio )

- Calculation $\mathrm{X}_{4}$ (Sales to Total Asset ratio )

Tabel. 3

Result of Rasio Calculation $X_{1}, X_{2}, X_{3}, X_{4}$

\begin{tabular}{|l|c|c|c|c|}
\hline Years & Score $\left(\mathbf{X}_{\mathbf{1}}\right)$ & Score $\left(\mathbf{X}_{\mathbf{2}}\right)$ & Score $\left(\mathbf{X}_{\mathbf{3}}\right)$ & Score $\left(\mathbf{X}_{\mathbf{4}}\right)$ \\
\hline $\mathbf{2 0 1 4}$ & $-0,13$ & $-0,15$ & $-0,38$ & 1,27 \\
\hline $\mathbf{2 0 1 5}$ & $-0,06$ & $-0,03$ & $-0,09$ & 1,15 \\
\hline $\mathbf{2 0 1 6}$ & $-0,11$ & -0 & $-0,01$ & 1,03 \\
\hline $\mathbf{2 0 1 7}$ & $-0,25$ & $-0,04$ & $-0,08$ & 1,11 \\
\hline
\end{tabular}

Resources : Result of Data Processing Year 2019

Calculation of Z-Score Value

\begin{tabular}{|c|c|c|c|c|}
\hline \multirow{5}{*}{$\begin{array}{c}\text { Z- Score } \\
\text { Value }\end{array}$} & \multicolumn{4}{|c|}{ YEARS } \\
\hline & 2014 & 2015 & 2016 & 2017 \\
\hline & $\begin{array}{l}=1,03 X_{1}+3,07 X_{2}+ \\
0,66 X_{3}+0,4 X_{4}\end{array}$ & $\begin{array}{l}=1,03 X_{1}+3,07 X_{2} \\
+0,66 X_{3}+0,4 X_{4}\end{array}$ & $\begin{array}{l}=1,03 X_{1}+3,07 X_{2}+ \\
0,66 X_{3}+0,4 X_{4}\end{array}$ & $\begin{array}{l}=1,03 X_{1}+3,07 X_{2} \\
+0,66 X_{3}+0,4 X_{4}\end{array}$ \\
\hline & $\begin{array}{l}=1,03(-0,13)+3,07(- \\
0,15)+0,66(-0,38)+ \\
0,4(1,27)\end{array}$ & $\begin{array}{l}=1,03(-0,06)+3,07 \\
(-0,03)+0,66 \quad(- \\
0,09)+0,4(1,15)\end{array}$ & $\begin{array}{l}=1,03(-0,11)+3,07 \\
(0)+0,66(0,01)+0,4 \\
(1,03)\end{array}$ & $\begin{array}{l}=1,03(-0,25)+3,07 \\
(-0,04)+0,66(-0,08) \\
+0,4(1,11)\end{array}$ \\
\hline & $=-0,3372$ & $=0,5497$ & $=0,3053$ & $=0,0109$ \\
\hline
\end{tabular}

The Zmijewski Model

- Calculation $\mathrm{X}_{1}$ (Earning After Tax to Total Assets ratio )

- Calculation $\mathrm{X}_{2}$ ( Debt Total to Total Assets ratio )

- Calculation $\mathrm{X}_{3}$ (Current Asset to Current Liabilities ratio )

Tabel. 4 
Result of Rasio Calculation $\mathbf{X}_{1}, \mathbf{X}_{2}, \mathbf{X}_{3}$,

\begin{tabular}{|c|c|c|c|}
\hline Years & Score $\left(\mathbf{X}_{\mathbf{1}}\right)$ & Score $\left(\mathbf{X}_{\mathbf{2}}\right)$ & Score $\left(\mathbf{X}_{\mathbf{3}}\right)$ \\
\hline $\mathbf{2 0 1 4}$ & $-0,12$ & 0,70 & 0,66 \\
\hline $\mathbf{2 0 1 5}$ & 0,02 & 0,71 & 0,84 \\
\hline $\mathbf{2 0 1 6}$ & 0 & 0,73 & 0,75 \\
\hline $\mathbf{2 0 1 7}$ & $-0,06$ & 0,75 & 0,51 \\
\hline
\end{tabular}

Resources : Result of Data Processing Year 2019

Calculation of X-Score Value

\begin{tabular}{|c|c|c|c|c|}
\hline \multirow{5}{*}{$\begin{array}{l}\text { X-Score } \\
\text { Value }\end{array}$} & \multicolumn{4}{|c|}{$\begin{array}{r}\text { YEARS } \\
\end{array}$} \\
\hline & 2014 & 2015 & 2016 & 2017 \\
\hline & $\begin{array}{l}=-4,3-4,5 X_{1}+5,7 X_{2} \\
-0,004 X_{3}\end{array}$ & $\begin{array}{l}=-4,3-4,5 X_{1}+5,7 \\
X_{-}-0.004 X_{3}\end{array}$ & $\begin{array}{l}=-4,3-4,5 X_{1}+5,7 \\
X_{2}-0,004 X_{3}\end{array}$ & $\begin{array}{l}=-4,3-4,5 X_{1}+5,7 \\
X_{2}-0.004 X_{3}\end{array}$ \\
\hline & $\begin{array}{l}=-4,3-4,5 \quad(-0,12)+ \\
5,7(0,70)-0,004(0,66)\end{array}$ & $\begin{array}{l}=-4,3-4,5(0,02)+ \\
5,7(0,71)-0,004 \\
(0,84)\end{array}$ & $\begin{array}{l}=-4,3-4,5(0)+5,7 \\
(0,73)-0,004(0,75)\end{array}$ & $\begin{array}{l}=-4,3-4,5(-0,06)+ \\
5,7(0,75)-0,004 \\
(0,51)\end{array}$ \\
\hline & $=0,22736$ & $=-0,34636$ & $=-0,142$ & $=0,24296$ \\
\hline
\end{tabular}

Discussion of Researh Result of Bankruptcy Prediction Using Altman Z-Score, Springate and Zmijewski Models Based Engineering Science

\section{The Altman Z-Score Model}

Based on reseach result at Garuda Indonesia and also refered to the Altman Z-Score certainty, concerning with a bankruptcy prediction,as follow : if $Z>2,60$, so the company was in a good condition, if $1,1<Z<2,60$ , so the company was in a grey areas, moreover if $\mathrm{Z}<1,1$, so the company was in a bad condition, or was in bankruptcy potential, as showed at tabel.5.

Tabel 5

Classification Result of Altman Z-Score Models on Garuda Indonesia Period Years of 2014 to 2017

\begin{tabular}{|c|c|c|c|c|c|c|}
\hline Years & Score $\left(\mathbf{X}_{\mathbf{1}}\right)$ & Score $\left(\mathbf{X}_{\mathbf{2}}\right)$ & Score $\left(\mathbf{X}_{\mathbf{3}}\right)$ & Score $\left(\mathbf{X}_{\mathbf{4}}\right)$ & Z-Score & Clasification \\
\hline $\mathbf{2 0 1 4}$ & $-0,13$ & $-0,08$ & $-0,15$ & 0,53 & $-1,5651$ & Bankruptcy \\
\hline $\mathbf{2 0 1 5}$ & $-0,06$ & $-0,06$ & 0,03 & 0,25 & $-0,1251$ & Bankruptcy \\
\hline $\mathbf{2 0 1 6}$ & $-0,11$ & $-0,06$ & 0 & 0,24 & $-0,6652$ & Bankruptcy \\
\hline $\mathbf{2 0 1 7}$ & $-0,25$ & $-0,12$ & $-0,04$ & 0,20 & $-2,09$ & Bankruptcy \\
\hline
\end{tabular}

Resources : Result of Data Processing Year 2019

Based on datas mentioned above could be interpretated, as :

The result of processing by using Altman Z-Score on Garuda Indonesia provided a bankruptcy potential during years of 2014 to 2017. The Z-Score value was in fluctuation and financial position was in distress condition. All these were attributable, as : $\left(\mathrm{X}_{1}\right)$ Working capital rasio was negative value cause of current liabilibies $>$ current asset, $\left(\mathrm{X}_{2}\right)$ Retained Earning rasio was negative value, $\left(\mathrm{X}_{3}\right)$ EBIT provided a low value and $\left(\mathrm{X}_{4}\right)$ book liabilities value > capital market value.

\section{The Springate Model}

Based on reseach at Garuda Indonesia and also refered to Springate certainty,with cut-off, if S- Score > 0,862 ,so is classificated as a healthy company and if $\mathrm{S}$ - Score $<0,862$,so is classificated as a bankruptcy company. The result of processing on company during years of 2014-2017 showed at tabel 6

\section{Tabel 6}

Classification Result of Springate Model on Garuda Indonesia Periode Years of 2014 to 2017

\begin{tabular}{|c|c|c|c|c|c|c|}
\hline Years & Score $\left(\mathbf{X}_{\mathbf{1}}\right)$ & Score $\left(\mathbf{X}_{\mathbf{2}}\right)$ & Score $\left(\mathbf{X}_{\mathbf{3}}\right)$ & Score $\left(\mathbf{X}_{\mathbf{4}}\right)$ & Z-Score & Clasification \\
\hline $\mathbf{2 0 1 4}$ & $-0,13$ & $-0,15$ & $-0,38$ & 1,27 & $-0,3372$ & Bankruptcy \\
\hline $\mathbf{2 0 1 5}$ & $-0,06$ & 0,03 & 0,09 & 1,15 & 0,5497 & Bankruptcy \\
\hline $\mathbf{2 0 1 6}$ & $-0,11$ & 0 & 0,01 & 1,03 & 0,3053 & Bankruptcy \\
\hline $\mathbf{2 0 1 7}$ & $-0,25$ & $-0,04$ & $-0,08$ & 1,11 & 0,0109 & Bankruptcy \\
\hline
\end{tabular}

Resources : Result of Data Processing Year 2019

Based on datas mentioned above could be interpretated, as : 
The result of processing by using S-Score on Garuda Indonesia provided a bankruptcy potential during years of 2014-2017. The S-Score value was in fluctuation and financial position was in distress condition. All these were result from: $\left(\mathrm{X}_{1}\right)$ Working capital rasio was negative value cause of current liabilibies > current asset, $\left(\mathrm{X}_{2}\right)$ EBIT provided a low value, $\left(\mathrm{X}_{3}\right)$ current liabilibies was higher than EBIT and $\left(\mathrm{X}_{4}\right)$ sales experienced a fluctuation during years of 2014-2017

\section{The Zmijewski Model}

Based on reseach at Garuda Indonesia and refered to the Zmijewski determinate, with cut-off, if X-Score $>0$, so is classificated as a bankruptcy potential company and if $\mathrm{X}$ - Score $<0$, so is classificated as a healthy company. The result of processing on company during years of 2014 -2017 showed at tabel 7

Tabel 7

Classification Result of Zmijewski Model on Garuda Indonesia

Periode Years of 2014 to 2017

\begin{tabular}{|c|c|c|c|c|c|}
\hline Years & Score $\left(\mathbf{X}_{\mathbf{1}}\right)$ & Score $\left(\mathbf{X}_{\mathbf{2}}\right)$ & Score $\left(\mathbf{X}_{\mathbf{3}}\right)$ & Z-Score & Clasification \\
\hline $\mathbf{2 0 1 4}$ & $-0,12$ & 0,70 & 0,66 & 0,22736 & Bankruptcy \\
\hline $\mathbf{2 0 1 5}$ & 0,02 & 0,71 & 0,84 & $-0,34636$ & Healthy \\
\hline $\mathbf{2 0 1 6}$ & 0 & 0,73 & 0,75 & $-0,142$ & Healthy \\
\hline $\mathbf{2 0 1 7}$ & $-0,06$ & 0,75 & 0,51 & 0,24296 & Bankruptcy \\
\hline
\end{tabular}

Resources : Result of Data Processing Year 2019

Based on datas mentioned above could be interpretated, as :

The result of processing by using X-Score on Garuda Indonesia provided a fluctuation condition during years of 2014-2017, where company experienced a bankruptcy potential in 2014 and2017, it caused of $\left(\mathrm{X}_{1}\right) \mathrm{Net}$ profit margin rasio was negative value,so the company experienced a disadvantage or loss of profit, moreover company showed a good condition in 2015 and 2016.

\section{Conclusion}

Based on result of reseach executed by using financial analysis rasio and analysis of Altman Z-Score, Springate and Zmijewski models could be concluded, as follow :

Financial performance analysis rasio, Garuda Indonesia had experienced a fluctuation condition since 2014 till 2017, where company financial performance was in unhelathy classification,with score value was $50 \%$ in 2014 and $35 \%$ in 2016 and 26,46\% in 2017, but company financial performance was in good condition in 2015, with score value was $72,14 \%$.

The result analysis of Altman Z-Score and Springate models proved that Garuda Indonesia had experienced a bankruptcy potential since 2014 till 2017, Meanwhile Zmijewski model showed that the company was in a healthy condition in 2015 and 2016. Based on clasification level of using three models to make a bankruptcy prediction of the company, Zmijewski model has a more accuration in bankruptcy prediction of the company than others one. The reason was reinforced by some researchers who had given an evidence of using Zmijewski model, as Fadrul and Ridawati (2020),conducted a research at the company of Pulp and Paper Indonesia, Anu Verma and Jyoti Pandit (2019) executed a research at six selected Public Sector Enterprises of India, M. Fakhri Husein and Galuh Tri Pambekti (2014) performed a research at 19 coal mining companies listed on IDX, and M. Fakhri Husein and Galuh Tri Pambekti (2014), analyzed on 132 companies which are attached on DES (Daftar Efek Syariah)

This reseach has a limitation, where scope of research focused just on Garuda Indonesia only. Furthermore research, we recommendate to compare with others airline, such as : Air Asia, Sriwijaya, Lion Air, Citilink, and Batik Air Airline,etc.

\section{Books}

\section{References}

1. Darsono. (2010), Financial Management. Jakarta. Nusantara Consulting.

2. Drescher, F. (2014). Insolvency Timming and Managerial Decision-Making. Springer, Munchen.

3. Fahmi, Irham (2016), Theory of Risk Management, Case and Solution, Rev..Ed. Bandung. Alfabeta.

4. Harahap, Sofyan Safri.(2013), Analysis Critical on Financial Reporting. Jakarta. Rajawali Pers.

5. Ismail. (2010), Bank Accountancy : Theory and Application, Rev.Edi. Jakarta Prenadamedia Group.

6. Kasmir (2014), Financial Reporting Analysis. Jakarta. Rajawali Pers.

7. Martani, Dwi dkk. (2012), Intermediate Financial Accountancy PSAK-Base, Book 1. Jakarta. Salemba Empat. 
8. Mulyadi. (2016). Cost Accountancy, 5,Ed. Yogyakarta. UPP Higher Learning for Management Science YKPN.

9. Musthafa. (2017). Financial Management. Yogyakarta: Andi Offset

10. Prihadi, Toto. (2010). Financial Reporting Analysis, Theory and Application. Jakart.PPM

11. Rodoni, Ahmad \& Herni Ali. (2014). Modern Financial Management. Jakarta. Mitra WacanaMedia

12. Samryn, L.M. (2012). Basic Accountancy : How to make Journal with Transaction Cycle Approach. Rev.Ed. Book 1, Jakarta. Rajawali Pers.

13. Subrahmanayan, K.R and Wild, John, (2010), Financial Statement Analysis, Mc Graw-Hill Education, USA.

14. Sugiyono. (2010). Quantitative Reseach Method $R \&$ \&. Bandung. Alfabeta.

15. Sutrisno, ( 2013). Financial Management: Theory,Concept and Application, 1st Ed.. Yogyakarta. Ekonisia.

\section{Journals}

17. Altman, Edward I. (1968). Financial Ratios, Discriminant Analysis and the Prediction of Corporate Bankruptcy, Journal of Finance, 589-609. https://doi.org/10.1111/j.1540-6261.1968.tb00843.x

18. Altman, E. I., Iwanicz-Drozdowska, M., Laitinen, E. K., \& Suvas, A. (2017). Financial Distress Prediction in an International Context: a Review and Empirical Analysis of Altman's Z-Score Model. Journal of International Financial Management \& Accounting. Vol. 28(2): 131-171.

19. Anu Verma and Jyoti Pandit (2019), An Analysis of Financial Distress of Selected Public Sector Enterprises of India Using Zmijewski X-Score Model. International Journal of Engineering Development and Research 2019 Vol. 7, Issue 1, ISSN: 2321-9939

20. Fadrul and Ridawati (2020). Analysis of Method Used to Predict Financial Distress Potential in Pulp and Paper Companies of Indonesia. International Journal of Economics Development Research, Volume I(1), 2020 pp. 57-69

21. Fifrianti, R. and Santosa, P. W. (2018). A Bankruptcy Prediction Analysis with Springate (Model (Case study at Telecomunication Industries,Ltd), Journal of Economics and Business Aseanomics, 3(1),

22. M. Fakhri Husein and Galuh Tri Pambekti (2014), Precision of the models of Altman, Springate, Zmijewski, and Grover for predicting the financial distress. Journal of Economics, Business, and Accountancy Ventura Vol. 17, No. 3, December 2014, pages 405 - 416

23. M.Noor Salim and Sudiono. (2017). an analysis of bankruptcy likelihood on coal mining listed firms in the indonesian stock exchange : an altman, springate and zmijewski approaches. eurasian journal of economics and finance, 3 (5), 99-108.

24. Ohlson, J.A. (1980). Financial Ratios and the Probabilistic Prediction of Bankruptcy. Journal of Accounting Research, 18(No.1).

25. Onakoya, A.B \& A. E. Olotu. (2017). Bankruptcy and Insolvency: An Exploration of Relevant Theories. International Journal of Economics and Financial Issues, 2017, 7(3): 706-712.

26. Peter dan Yosep. (2011). Bankruptcy Analysis with Z-Score Altman, Springate and Zmijewski Methods (Case study at Indofood Sukses Makmur,Ltd)

27. Santosa, P. W. (2010) Longterm Trends Analysis of Managing Expectation for Active Value. Jurnal Akuntansi dan Keuangan. 12(2), 94-115,

28. Sari, E.W. (2014). Application of Zmijeski, Springate, Altman Z-Score, and Grover models in Bankruptcy Prediction on Public Transportation Listed on Indonesian Stock.

29. Setiadi, A. (2011), Financial Distress Analysis on bankruptcy prediction with Altman's Z-Score model( Case study at Bakrie \& Brothers, Ltd)

30. Springate, Gordon L.V. (1978). Predicting the Possibility of Failure in a Canadian Firm. M.B.A. Research Project, Simon Fraser University.

31. Venkataramana, et.a (2012). Financial Performance and Predicting the Risk of Bankruptcy: A Case of Selected Cement Companies in India. International Journal of Public Administration and Management Research 1: 40-56.

32. Zmijewski, Mark. (1983). Predicting Corporate Bankruptcy: An Empirical Comparison of the Extant Financial Distress Models. Working paper. SUNY at Buffalo.

\section{3. www.idx.com}

